\title{
O transformacji i konsolidacji - spojrzenie krytyczne
}

$\mathbf{T}$

ekst Nicolasa Guilhota i Philippe'a C. Schmittera dotyczy poważnego problemu, z którym przedstawiciele nauk społecznych nie tylko w Polsce nie umieli sobie do końca poradzić na przestrzeni ostatnich 20 lat - kwestii odkrycia/skonstruowania paradygmatu transformacji ustrojowej ${ }^{1}$. Jego autorami są uznani badacze procesów, które rozpoczęły się właśnie w Polsce, dlatego warto go poddać dokładniejszej analizie.

Zadanie, jakie uczeni stawiają przed sobą jest sformułowane explicite „zbadać nowy status epistemologiczny, który charakteryzuje studia na temat konsolidacji"2.

Jedną z największych wartością tekstu jego pedagogiczny charakter dzięki niemu możemy w sposób syntetyczny zapoznać się z podstawowymi założeniami teorii transformacji i konsolidacji. Mimo iż definicje obydwu pojęć mają charakter rozproszony, możemy wyrobić sobie zdanie na temat

Uwagi na ten temat obecne są w licznych tekstach z zakresu nauk społecznych. W kontekście dociekań polskich warto przytoczyć takie publikacje, jak: J. Staniszkis, W poszukiwaniu paradygmatu transformacji, w: W poszukiwaniu paradygmatu transformacji, Warszawa 1994, s. 5-34; J. Szacki, Nauki społeczne wobec wielkiej zmiany, w: Zmiana społeczna, red. J. Kurczewska, Warszawa 1999.; R. Sojak, D. Wicenty, Zagubiona rzeczywistość: o społecznym konstruowaniu niewiedzy, Warszawa 2005.

2 N. Guilhot, P. C. Schmitter, Od transformacji do konsolidacji. Retrospektywny przeglad studiów przypadku demokratyzacji, przeł. A. Owczarz, „Dialogi Polityczne” 2009, nr 11, s. 18. 
możliwości głównych kierunków badań wyznaczonych przez każdą z koncepcji oraz ich implikacji poznawczych i pozapoznawczych.

Największą wadą tego wybitnie teoretycznego tekstu jest brak jakichkolwiek odniesień do badań empirycznych. Taka forma tekstu dziwi tym bardziej, iż jednym z podstawowych zagadnień epistemologii jest relacja między opisem (tu: modelem, teorią) i tym, co opisywane (rzeczywistością). W takim wypadku należy uznać już na początku, iż autorzy nie w pełni wywiązali się z postawionego sobie zadania.

Jak sugeruje dogłębne przestudiowanie tekstu, autorzy zdają się uważać, że o wyższości jednego modelu nad drugim przesądza jego wewnętrzna spójność i logiczna niesprzeczność, a nie możliwość adekwatnego opisu maksymalnej liczby zjawisk z danego zakresu. Potraktowanie teorii jako swoistego bytu autoreferencyjnego nie tylko nie sprzyja badaniom empirycznym, ale (być może przede wszystkim) utrzymuje nauki społeczne w stanie permanentnego kryzysu związanego z niemożliwością formułowania sprawnych dyrektyw praktycznych (politycznych) oraz skutecznych predykcji ${ }^{3}$.

Wątpliwości budzi również szereg założeń teoretycznych formułowanych przez autorów, a nie mających żadnych podstaw natury epistemologicznej czy metodologicznej. Guilhot i Schmitter uznają za Clausem Offem, iż „relacja między instytucjami i normami [...] nie jest jednostronna, lecz wzajemna i kolista"4, co w terminologii przyjętej w polskiej literaturze możemy uznać za sprzężenie zwrotne czy też wzajemne warunkowanie się. Taki proces zachodzi według autorów w przypadku systemu będącego w stanie equilibrium. Gdy jednak dochodzi do radykalnej zmiany fundamentów ładu politycznego, relacja ta miałaby już nie zachodzić. Warunkowanie się norm i instytucji miałoby mieć $\mathrm{w}$ tym wtedy charakter przyczynowo-skutkowy. Jedynym problemem jest znalezienie mitycznego „pierwszego poruszyciela”.

Co sprawia, że koncepcja wzajemnego warunkowania w tym przypadku nie działa - nie wiadomo. Dziwi to tym bardziej, iż proponowana w przytoczonym cytacie Offe'a, relacja instytucji i norm niemalże idealnie pokrywa się z koncepcją pola i habitusu obecnej w publikacjach Pierra Bourdieu' Francuski socjolog nie badał wprawdzie zmiany podstaw funkcjonowania systemów politycznych, lecz jego dociekania z zakresu przemian w środowisku akademickim zaprezentowane w Homo Academicus ${ }^{6}$ czy zmian w zakresie regulacji dotyczących rynku mieszkaniowego we Francji, o czym pisze

Patrz: P. Bourdieu, Loic J. D. Wacquant, Zaproszenie do socjologii refleksyjnej, Warszawa 2001.

N. Guilhot, P. C. Schmitter, dz. cyt., s. 20.

Patrz: P. Bourdieu, In Other Words, Cambridge 1990.

P. Bourdieu, Homo Academicus, Stanford 1988. 
w Social Structures of Economy ${ }^{7}$, które skłaniają do stwierdzenia, iż wzajemne warunkowanie się struktur instytucjonalnych i indywidualnych wzorów działania zdają się odpowiadać sobie nawet w czasach wielkich przemian. Nie widzę powodu, dla którego przeobrażenia samych fundamentów działania w dziedzinie polityki miałyby w tym wypadku stanowić jakościową różnicę. Nawet jeśli tak jest, Guilhot i Schmitter powinni podać merytoryczne argumenty na rzecz swojej tezy, czego nie robią.

Fakt, iż w tekście dokonany zostaje sumienny przegląd założeń koncepcji zarówno transformacji, jak i konsolidacji, umożliwia badaczom zapoznanie się z interesującymi zmiennymi, które należy brać pod uwagę, badając procesy, jakie zaszły w Polsce w trakcie całej drogi od komunizmu. Jedno $\mathrm{z}$ wielu interesujących założeń daje badaczowi „transformologia”. Według autorów zakłada ona, iż w czasach przemian „,nowe reguły i procedury zostały wypracowane w ograniczonym kontekście i przez wąską elitę, zanim przyswoił je i «zasymilował» szerszy zbiór jednostek". . Fakt zaistnienia takiego procesu potwierdzają słowa profesor Leny Kolarskiej-Bobińskiej: „Reformy rynkowe zostały uzgodnione przez elity antykomunistyczne i te wywodzące się z dawnego systemu, a następnie wprowadzone przy aprobacie różnych międzynarodowych instytucji. Również inne reformy - m.in. terytorialna, ubezpieczeń społecznych czy edukacji - nie były konsultowane w Polsce w istotnym stopniu ze społeczeństwem"'. Ogromną zaletą analizy Guilhota i Schmittera jest zwrócenie uwagi na zmienne, które do dziś znajdują się raczej na obrzeżach zainteresowań badaczy społecznych, a których analiza, ze względu na swoją istotność powinna być znacznie bardziej pogłębiona ${ }^{10}$.

Słabą stroną tekstu jest fakt pojawiania się w nim tez banalnych. Autorzy nie stawiają sobie również pytań bardziej wyrafinowanych, nie mówiąc już o próbie operacjonalizacji. „Transformacje są także - co samo przez się zrozumiałe - okresami, w których istniejące kombinacje są często przypadkowe i podczas których można popełnić wiele błędów"11 - trudno o postawienie bardziej oczywistej tezy. Zdecydowanie brakuje w tym miejscu refleksji nad problemem rozróżnienia działań (w tym błędów) intencjonalnych i spontanicznych. Jakie jest kryterium odróżnienia przypadkowych

\footnotetext{
P. Bourdieu, The Social Structures Of The Economy, Cambridge 2000.

N. Guilhot, P. C. Schmitter, dz. cyt., s. 21.

L. Kolarska-Bobińska, Kłopoty z demokracja, „Europa” dodatek do gazety „Dziennik. Polska, Europa, Świat" 2007, nr 15 s. 8-9.

10 Spośród publikacji poświęconych elitom można wymienić: J. Nocoń, Elity polityczne. Studium interpretacji funkcjonalnej, Toruń 2004; W. Hładkiewicz, Ewolucja i zróżnicowanie polskich elit politycznych, w: Piętnaście lat doświadczeń polskiej transformacji, red. W. Hładkiewicz, M. Szczerbiński, Zielona Góra 2004.

$11 \quad$ N. Guilhot, P. C. Schmitter, dz. cyt., s. 22.
} 
kombinacji i tych wytworzonych celowo? Jak oddzielić błędy spowodowane niedostateczną wiedzą, a jak te, za którymi stoją świadome motywacje? Na te i podobne pytania próżno szukać odpowiedzi w tekście.

Autorzy analizując prace Samuela Huntingtona, przytaczają jego interesującą tezę, iż „stabilizacja oraz, a fortiori, demokracja nie są naturalnym efektem modernizacji" ${ }^{\prime 2}$. Liczne historyczne i współczesne przykłady potwierdzają brak takiej zależności. Głośne referendum w Lichtensteinie z 2003 roku pokazało jednak, iż społeczeństwo może (w ramach demokracji) dobrowolnie ograniczyć działanie demokratycznie wybranego parlamentu i przekazać część władzy niedemokratycznemu władcy ${ }^{13}$. Nie musi to być efektem degeneracji systemu i powodować zapowiadanego przez Huntingtona chaosu. Tekst Guilhota i Schmittera pochodzi z 2000 roku i tych wydarzeń nie mógł przewidzieć. Wymusza to jednak potrzebę krytycznego ustosunkowania się do dociekań autora Zderzenia cywilizacji.

Założeniem budzącym moje największe zastrzeżenia jest potraktowanie przez autorów, za tekstem Philippe'a Schmittera i zgodnie z teorią konsolidacji, zinstytucjonalizowanych norm jako zmiennej niezależnej, która ma tłumaczyć zmianę zachować podlegających regulacjom podmiotów. Jak piszą autorzy: „Zachowanie podmiotów jest więc rozważane jako zdeterminowane przez struktury i skodyfikowane przez normy konstytucyjne i polityczne, aten proces strukturyzacji powinien uczynić owo zachowanie bardziej przewidywalnym"14. Takie potraktowanie prawa wynika z przyjętego przez autorów, a skrytykowanego już powyżej, założenia o linearnym charakterze oddziaływania w relacji instytucje - normy.

W rzeczywistości nauki społeczne, aby zrozumieć jakiekolwiek przemiany społeczne, w tym te związane $\mathrm{z}$ transformacją, muszą zabiegać o badanie na polu, które nazywam „społeczną historią prawa”. Regulacje, normy konstytucyjne i przepisy, którym mają podlegać podmioty moralne nie pojawiają się znikąd. Są one efektem intencjonalnych lub nieświadomych działań mających na celu osiągnięcie określonej formy prawa. W tej perspektywie to ostateczny kształt rozporządzeń jest stawką w grze, która angażuje liczne środowiska - od biznesmenów przez lobbystów, związki zawodowe, dziennikarzy, aż po polityków. Empirycznym dowodem na to, iż ostateczny kształt prawa jest efektem gry interesów, czyli efektem relacji władzy, jest tzw. afera Rywina, której stawką były właśnie określone regulacje prawne. Narzędzi do analizy takich przypadków dostarczył George Joseph Stigler,

\footnotetext{
Tamże, s. 29.

Zob. TS, Liechtenstein, „Gazeta Wyborcza” 2003, nr 66, s. 13.

N. Guilhot, P. C. Schmitter, dz. cyt., s. 27.
} 
laureat Nagrody Nobla w dziedzinie ekonomii w 1982 roku. W swoim tekście The Theory of Economic Regulation analizował on ten sam mechanizm w kontekście Stanów Zjednoczonych ${ }^{15}$.

Przykłady te dowodzą, iż nieuprawnionym zabiegiem Guilhota i Schmittera jest założenie o linearnym charakterze zależności między instytucjami a normami. Być może w każdym kontekście mają one charakter sprzężenia zwrotnego. Przytoczony przez autorów cytat z Offe'a: „nie tylko ludzie tworzą instytucje, ale również instytucje tworzą ludzi”"16 ma najprawdopodobniej uniwersalny charakter.

Tekst z pewnością skłania do refleksji nad zagrożeniami dla demokracji, które (paradoksalnie) są immanentne temu systemowi. Wartościową koncepcją jest tu z pewnością przytoczona teoria O’Donella wskazująca możliwość „zamrożenia” „niekompletnych instytucji demokratycznych, ograniczonych lub źle funkcjonujących, w trosce o ustabilizowanie i skonsolidowanie zmian w naturze ustroju" ${ }^{17}$. Odnosząc tę uwagę do kontekstu polskiego, należy się zastanowić, czy niezdolność jakiegokolwiek rządu do przeprowadzenia reformy sądownictwa, prokuratury, policji ${ }^{18} \mathrm{i}$ innych rdzeniowych instytucjach państwa na przestrzeni ostatnich 20 lat nie jest przykładem potwierdzającym, że pomimo wskazanych przez Guilhota i Schmittera problemów teoretycznych, zjawisko opisane przez o’Donella może mieć miejsce w młodych demokracjach.

Wywód Guilhota i Schmittera jest tekstem wartościowym i inspirującym do stawiania dalszych pytań. Zarówno młodzi, jak i bardziej doświadczeni badacze z pewnością znajdą tu wiele interesujących wątków, które mogą przyczynić się do jeszcze bardziej dogłębnego dociekania mechanizmów rządzących przemianami ustrojowymi w Polsce ostatnich 20 lat. Śladowe przypadki operacjonalizacji tez oraz brak jakichkolwiek odniesień do empirii sprawiają, iż forsowane przez autorów nowe ujęcie koncepcji konsolidacji oczekuje na badania umożliwiające konfrontację koncepcji z rzeczywistością i innymi, bazującymi na odmiennych założeniach opisami wielkich przemian politycznych i gospodarczych.

M A T E U S Z T R A W I Ń S K I

15 G. J. Stigler, The Theory of Economic Regulation, 1971, [http://faculty.msb.edu/murphydd/ cric/readings/Stigler--Th\%20of\%20Econ\%20Regulation\%201971.pdf; dostęp: 8 czerwca 2009].

16 N. Guilhot, P. C. Schmitter, dz. cyt. s. 26.

17 Tamże, s. 31.

18 Hipotezę na temat instytucjonalizacji patologii w ramach prokuratury i policji potwierdzają liczne wątki sprawy zabójstwa Krzysztofa Olewnika. 